\title{
UM FAZER ARTE-ETNOGRÁFICO: MEMÓRIAS DE MULHERES NUM ESPAÇO DE CO-CRIAÇÃO E AFETOS
}

\author{
Sandra Maria Costa dos Passos Colling ${ }^{1}$ \\ Ana Luiza Carvalho da Rocha ${ }^{2}$
}

\section{Introdução}

Este trabalho apresenta o processo de construção da dissertação Da caixa de música ao perfume, tudo é tesouro! Estudo etnográfico sobre mulheres em processo de envelhecimento e seus objetos de penteadeira na região do Vale do Rio dos Sinos $/ R^{3}$ desde a perspectiva de escrita de novas narrativas etnográficas e suas contribuições para os avanços de um paradigma das formas sensíveis para o conhecimento antropológico. Em especial, abordaremos o formato adotado para a produção do espaço livresco da obra (a dissertação), onde a busca de convergência das suas estruturas gráfica e diegéticas com as experiências das parceiras da pesquisa desempenharam papel relevante na descrição das categorias etnográficas (envelhecimento, memória e gênero) empregadas pela autora.

A obra mencionada parte dos relatos das experiências geracionais com o processo de envelhecimento de uma rede social de mulheres de camadas medias urbanas da região do Vale do Sinos/RS, com idades entre 62 e 102 anos. Através da observação participante do/no cotidiano da vida privada destas mulheres e de entrevistas não diretivas sobre suas trajetórias sociais, memórias familiares e biografias foi possível, progressivamente, se pensar novas possibilidades de organização da escrita etnográfica num diálogo progressivo com a estética dos jogos da memória por elas apresentados, alinhando a estrutura da dissertação a singularidade de cada uma das experiências com elas compartilhadas.

\footnotetext{
${ }^{1}$ Universidade Feevale, Brasil. E-mail: sandracolling@gmail.com ORCID id: https://orcid.org/0000-0003-3094-1111

${ }^{2}$ Universidade Feevale, Brasil. E-mail: miriabilis@gmail.com ORCID id: https://orcid.org/0000-0002-2294-5932

${ }^{3}$ Este artigo aborda um fragmento da dissertação de Mestrado em Processos e Manifestações Culturais realizado de 2017 a 2019, na Universidade Feevale, intitulada "Da caixa de música ao perfume, tudo é tesouro! Estudo etnográfico sobre mulheres em processo de envelhecimento e seus objetos de penteadeira na região do Vale do Rio dos Sinos/RS”, financiada pela CAPES. Prévia destas considerações foram apresentadas na XIII RAM - Reunião de Antropologia do Mercosul, realizada em Porto Alegre, 2019.
} 
Os 'objetos de penteadeira' guiaram, assim, a produção gráfica da obra, não apenas a descrição etnográfica dos fenômenos pesquisados (envelhecimento, gênero, memória) uma vez que ela própria (a dissertação) foi transformada em um "guardado" onde repousavam as memórias das experiências compartilhadas da pesquisadora com suas interlocutoras. Para a produção dessa escrita antropológica, a autora explorou a sua formação de origem, a do campo da arte, articulada a sua formação, ao longo do processo de orientação durante curso de mestrado, em antropologia social.

Tratava-se de buscar outros modos de promover a descrição etnográfica, explorando, no ato de ler e explorar o espaço livresco, o ato de tocar, sentir, perceber o ponto de vista singular e irredutível das interlocutoras da pesquisa sobre sua condição de gênero em presença do processo de envelhecimento. Da mesma forma, a autora procurava observar, na forma adotada para cada um dos capítulos da dissertação, a estética por meio da qual poderia descrever o arranjo na composição ética dos jogos de memória daquilo que lhe era narrado, em especial tudo aquilo ao qual aludiam, de forma indireta, e cujos indícios "permitem ao observador perceber ou sentir outros níveis da realidade" (Leite, 2001: 76).

Diante do fato de muitas destas mulheres não terem registros fotográficos anteriores, o que importava era aproximar a estrutura gráfica e diegética da dissertação nas lembranças narradas por elas, no sentido de sua forma permitir ao leitor mergulhar nos jogos de suas memórias e, assim, não apenas descrever os fenômenos investigados “de perto e de dentro" (Magnani, 2002: 18), mas conduzi-lo a viver uma experiência singular de ser afetado por tais recordações. As leituras promovidas pelo blog Livro do Etnógrafo $^{4}$ do Banco de Imagens e Efeitos visuais foram, sob essa ótica, essenciais.

As formas, as imagens e as palavras são mediadoras dessa escrita etnográfica que apresentamos a seguir, e com elas vão se desenhando costuras entre os estudos teóricos sobre memória, envelhecimento e gênero e alguns dos efeitos da própria pesquisa de campo, sob o desafio de sua "recriação imaginativa", nos termos propostos por Marilyn Strathern (2014: 345).

Demonstrar relações entre as narrativas de mulheres em processo de envelhecimento e as experiências que elas estabelecem com seus objetos de penteadeira traz a necessidade de aprimorar, na pesquisa de campo, não apenas as habilidades de uma

\footnotetext{
${ }^{4}$ A respeito consultar o site http://bievufrgs.blogspot.com/ Blog do Grupo de Trabalho sobre escrita e representação etnográfica do Biev - Banco de Imagens e Efeitos Visuais - Programa de Pós-Graduação em Antropologia Social, Universidade Federal do Rio Grande do Sul.
} 
escuta sensível a própria forma como a narrativa sobre tais objetos são tecidas, mas a perícia de transpô-las como parte integrante da própria forma da descrição etnográfica a ser adotada pela artista plástica aprendiz de antropóloga.

O que nos faz lembrar, para o caso, a importância de se problematizar as produções antropológicas, desde a afirmação de Pierre Bourdieu (2011b: 7), como fenômeno que integra o campo das produções culturais, ou seja, cujo "o poder simbólico" que dele emana precisa ser discutido uma vez que, segundo o autor tal poder se caracteriza como tal por ser "invisível" e pode ser "exercido com a cumplicidade daqueles que não querem saber que lhe estão sujeitos ou mesmo que o exercem".

As imposições da sociedade no interior das representações etnográficas como parte de práticas culturais. Assim, essa pesquisa valoriza a participação e o trabalho científico de construção de uma dissertação ou tese. O homo academicus, nos termos de Bourdieu (2011a) e o capital social e cultural da Antropologia e a etnografia da duração.

A proposta de estrutura narrativa e, por sua vez, da sua composição como obra gráfica parte do aceite do desafio da pesquisadora em se apresentar na figura do narrador (Eckert e Rocha, 2005) e onde a escrita etnográfica que a compõe não apenas problematiza aquilo que está "por detrás" da tradução dos significados culturais mas reflete os dilemas da própria tríade autor/tradutor/texto na conformação da prática investigativa do trabalho de campo em relação as estórias narradas pelas suas parceiras de pesquisa.

A opção pela modalidade de fascículos destinados a cada uma das narradoras, reunidos no volume da dissertação, opera com as próprias fronteiras do conhecimento antropológico ao inscrever a composição gráfica da obra no interior do próprio trabalho de campo que a pesquisadora realizou e no seu esforço em compreender e descrever as formas de viver e de pensar o envelhecimento entre um grupo de mulheres de uma cidade de porte médio do sul do Brasil a partir de seus "guardados".

A pesquisadora, aos poucos, apresenta-se ao leitor da obra na figura do antropólogo-narrador "herdeiro de uma certa comunidade linguística, ela própria uma comunidade de vida" (Eckert e Rocha, 2004: 1), sendo a escrita o momento singular de expressão das trocas sociais e de afetos vivida pela pesquisadora com as suas parceiras de aventura. Um desafio que foi proposto nos termos do que vem sendo realizado pela equipe do Banco de Imagens e Efeitos Visuais, da UFRGS, com quem a autora da dissertação vem mantendo estreitos laços intelectuais e acadêmicos. 
A leitura dos inúmeros artigos, na Revista Iluminuras foram, neste sentido, importantes fontes de inspiração, e muito em particular, referimo-nos aos artigos sobre o tema da desterritorialização/descolonização dos saberes e fazeres antropológicos pela via da crítica ao estatuto da escrita na construção da representação etnográfica (Barroso et al., 2008a, 2008b). Nestes artigos, os autores assinalam as diferenças da etnografia fora do trabalho de campo e no interior do corpo da letra, situação de uma epistemologia outra, onde a escrita antropológica desponta como coisa política em sua busca por retraçar, em suas descrições dos dados de campo, o diálogo entre um conjunto comum partilhado de saberes, do qual resultam os estudos monográficos dos antropólogos como partilha entre saberes cotidianos e saberes científicos, entre o que pertence ao 'nativo' e o que compete ao etnógrafo.

De igual forma, o artigo sobre a construção de narrativas etnográficas a partir de tecnologias audiovisuais (Rocha, 2003; Rocha e Eckert, 2016) foi crucial para o entendimento das relações histórica e genealógica da descrição etnográfica da Antropologia com a produção escrita e impressa e, por derivação, com o espaço livresco. Muito especialmente, quando a autora, com base nas reflexões de Jacques Rancière (1995, 1996) assinala o caráter singular a tradição literária que adota o registro dos dados de campo para caso das práticas escriturísticas da Antropologia. Ou seja, as influências que ela exerce na forma como escrita antropológica procura expressar, no plano diegético, as relações do etnógrafo com o outro bem como restaurar, no ato da escrita, as posições diferentes desde onde a palavra viva desse outro foi capturada/exilada. Uma escrita que, em seu sentido mais amplo possível, procura insistentemente devolver a este outro a sua 'assinatura no mundo'.

\section{A dissertação e a arte de tramar os fios de narrativas biográficas}

A escritura da dissertação acompanha o passo a passo do trabalho em campo da pesquisadora que serviu como roteiro $^{5}$ para a estrutura da obra, sendo pouco a pouco acompanhada do relato do acontecimento que representou para a autora as leituras das áreas da história social e da antropologia urbana e visual, bem como de realização de algumas atividades artísticas pela aprendiz de etnografia com as suas parceiras de

\footnotetext{
${ }^{5}$ Visita inicial para explicação sobre a pesquisa e assinatura de Termo de Consentimento; visitas para realização da etnografia (narrativas e imagens).
} 
pesquisa como fechamento do trabalho de campo, e que vão compor a estrutura gráfica do trabalho final.

É importante lembrar que “[...] narrar já é 'refletir sobre' os acontecimentos narrados. Nesse sentido o 'tomar juntamente' narrativo comporta a capacidade de se distanciar de sua própria produção e, consequentemente, de se desdobrar" (Ricouer, 2010: 104, grifo do autor). Esse distanciamento foi um exercício constante na escrita etnográfica. As etapas ${ }^{6}$ de pesquisa foram se alternando e relacionando.

Com atenção especial à significação dos objetos e suas relações com as mulheres envolvidas, a escrita trouxe olhares e perspectivas singulares sobre o objeto de estudo. Segundo Foucault (2001: 272) “o sujeito que escreve não pára de desaparecer”. Assim como a arte, a escrita está para além de quem escreve. Durante o processo emergiram necessidades inerentes ao ser humano, de experimentar, de relacionar coisas e fatos, de associar, ligar, religar e se completar. E, por este motivo, cada momento vivido na investigação foi de extrema tensão e, também, de sutil leveza.

Pois a realidade é exatamente isso: um estado de tensão a todo instante entre o ser e o não-ser, um estado no qual tanto o ser como o não-ser são irreais e só é real a constante interação entre ambos, o devir deles. A forma é a manifestação de um estado de equilíbrio alcançado em um determinado momento (Fischer, 1983: 143)

Sobre a montagem da dissertação, em um determinado momento foi possível perceber que as anotações sobre cada uma das parceiras de pesquisa formavam um texto muito mais fluído, interessante de se ler porque elas traziam muitas informações e essas informações misturadas poderiam se perder. Lendo e relendo as escritas, observando a importância da continuidade de pensamento no momento da leitura, houve a necessidade de se montar a dissertação em formato de fascículos ${ }^{7}$. Afinal,

Toda expressão dotada de significado, e, portanto, toda experiência e todo entendimento, é uma espécie de invenção, e a invenção requer uma base de comunicação em convenções compartilhadas para que faça sentido - isto é, para que possamos referir a outros, e ao mundo de significados que compartilhamos com eles, o que fazemos, dizemos e sentimos (Wagner, 2010: 76).

\footnotetext{
${ }^{6}$ Visitas; transcrição das gravações; observação dos vídeos; leitura dos teóricos; escrita e reescrita a partir destas relações (teoria e campo etnográfico); observação de postagens das parceiras de pesquisa na internet; ${ }^{7}$ Fascículo I: o início da pesquisa, da base que fundamenta a investigação, o problema, a justificativa, objetivos, a metodologia, enfim os teóricos que seriam estudados, a localização da área, alguns dados do IBGE. Fascículo II: mostra a rede social formada, desde a entrada em campo até a apresentação das sete mulheres parceiras de pesquisa. Fascículo III ao IX: narrativas, imagens e relação com a teoria, sendo cada fascículo sobre cada uma das mulheres em processo de envelhecimento. Fascículo X: considerações finais da pesquisa.
} 


\section{Sandra Maria Costa dos Passos Colling e Ana Luiza Carvalho da Rocha}

Como foram coletadas muitas gravações e imagens, esses materiais foram apresentados às mulheres em uma outra visita como uma forma de dar retorno a todo tempo que elas dedicaram à pesquisa e à pesquisadora, para que se pudesse então dar como encerrada a investigação. Porém, nesse mesmo tempo surgiu a ideia de fazer com que elas pudessem refletir sobre as coisas que tinham pensado e falado durante esse tempo e convidá-las para que pudessem elaborar as capas de cada um de seus fascículos, deixando-as livres para escolher a técnica que gostariam de usar para elaborar cada um deles $^{8}$, enquanto a pesquisadora se envolveu na montagem ${ }^{9}$ artística para a dissertação, pensando-a como um livro de artista-etnógrafo, afinal era o que se apresentava de fato.

Ao utilizar o espaço do tecido de forma livre, estas mulheres reviveram os momentos marcantes relembrados durante a pesquisa, fazendo deste tecido o seu campo, onde foi possível perfurar, colar, recortar, marcar, entrecruzar, realizar gestos que narram cada uma delas. O que se apresenta é uma escrita carregada de construtos sociais, de seus percursos, fazeres e saberes. O trabalho realizado por cada interlocutora desta pesquisa trata-se de um "arranjo poético" de sua vida narrada (Eckert, Rocha, 2010: 131). Antropologia e arte numa construção colaborativa, numa co-criação entre pesquisadora e parceiras de pesquisa, com respeito e ética, onde é fato que

O conhecimento antropológico nos moldes de cooperação seguiria, assim, uma ética discursiva pela qual os antropólogos e seus interlocutores de pesquisa se reconhecem mutuamente portadores dos mesmos direitos de produção de conhecimento sobre si e o mundo (Rocha, Eckert, 2017: 34).

Muitas formas e técnicas apresentadas são herdadas de seus antepassados, e continuarão sendo deslocadas, dentro deste espaço familiar, de forma a constituir a trajetória deste grupo. São contratos que se firmaram no desejo de continuidade, de perpetuação, onde as imagens apontaram a marca do outro. "Misturam-se as almas nas coisas, misturam-se as coisas nas almas. Misturam-se as vidas, e assim as pessoas e as

\footnotetext{
${ }^{8}$ Cada mulher recebeu três pedaços de tecido, tamanho $12 \times 12 \mathrm{~cm}$, de algodão cru. Tiveram três semanas para elaborar o material artístico.

${ }^{9}$ A pesquisadora desenhou uma mini penteadeira e montou-a em madeira (com gravação dos nomes das participantes, da pesquisadora, orientadora, título da pesquisa), juntamente com mini objetos e um pequeno baú. Também confeccionou marcadores de página com imagens das residências e dos rostos das mulheres. Preparou um mini caderno com imagens realizadas durante a etnografia. Em papel A4 kraft (papel resistente fabricado a partir de uma mistura de fibras de celulose curtas e longas, provenientes de polpas de madeiras macias) foi bordado o número de cada fascículo, onde mais tarde foi costurada cada capa produzida pelas parceiras de pesquisa.
} 
coisas misturadas saem cada qual de sua esfera e se misturam: o que é precisamente o contrato e a troca" (Mauss, 2015: 210).

\section{Alinhavando as narrativas e entrelaçando com as imagens da pesquisa}

As imagens produzidas pelas interlocutoras da pesquisa trazem a força das reminiscências advindas durante a pesquisa etnográfica sobre a relação das mulheres em processo de envelhecimento e seus objetos de penteadeira. Revisitando estas imagens é possível refletir sobre sua dimensão colaborativa, apresentando sua experiência relacional com os objetos e com a pesquisadora.

A prática realizada trata dos processos de pesquisa onde as interlocutoras são coprodutoras de conhecimento. Os movimentos que ocorreram durante a investigação foram de trocas e produção colaborativa e afetiva do material de pesquisa. A autoria desta pesquisa representou boa parte da partilha de uma experiência de trabalho de campo traduzida num livro de artista-etnógrafo. Lugar de transposição, via escrita, de acontecimentos onde se tramam saberes e fazeres há muitas mãos, uma obra tecida com o entrecruzar do conhecimento entre as partes envolvidas e, para além delas, numa expansão que não pode ser medida porque se abre, duplica e replica por meio de cada leitor(a), como assinalam Matheus Cervo e Ana Luiza Rocha (2019) para o caso do projeto O livro do etnógrafo. Afinal, "o mundo é tecido de livros: não apenas imaginário partilhado, mas textos que são todos compartilhados da mesma maneira" (Rancière,1995: $68)$.

Desse modo, esta experiência partilhada trouxe imagens múltiplas para as capas de cada capítulo da dissertação. Nelas vemos uma águia, flores variadas que saem para fora da margem do tecido e letras misturadas onde a palavra 'sonhos' se reúne com a palavra 'sons' entre outras letras e linhas. Em outras, flores, traços e cores suaves feitos pelas mãos de uma mulher de 102 anos de idade.

Tecidos, linhas e botões reforçando camadas sobrepostas, com força e vigor nos movimentos de outra. Por outro lado, observamos a delicadeza no traçado que traz uma mulher com uma criança no colo, um campo num dia ensolarado e uma árvore de Natal rodeada de pacotes e estrelas. A cada gesto, a partilha se faz e o conhecimento se constrói, se mostra e se expande. 
Já em outros tecidos, estão presentes flores variadas por meio da técnica do fuxico. Os retalhos utilizados são, em sua maioria, em cores vibrantes, estando acompanhados por tiras recortadas de tecido em alguns detalhes. Estas imagens lembram o jardim da casa da interlocutora, tantas vezes visitada nesta pesquisa por meio das contações que envolvem plantar e observar crescer, assim como a pesquisa se fez. E então, a colheita é partilhada.

Em outro fazer a interlocutora sai da planificação do tecido utilizando colagens de materiais diversos, dobraduras, escrita, crochê, fotografia e costura. Flores, corações e borboletas compõem o cenário metafórico de suas rememorações e apresentam a leitura de mundo desta mulher. O que podemos observar desta trajetória e do aprendizado de vida que nos ensina agora?

Uma das mulheres surpreende a pesquisadora ao trazer todas as três capas no mesmo formato: apenas com um crochê em vermelho nas bordas, tendo o restante do tecido exatamente como foi entregue a ela. Como elas tinham liberdade para realização da tarefa é muito interessante que imagens como esta surjam. Este campo aberto nos diz algo sobre nosso movimento e ocupação no espaço.

Cada parceira apresenta o que os nossos encontros provocaram. É possível observar a imagem de Nossa Senhora das Graças, um terço, o formato de uma mão e uma flor de cor neutra. Esta interlocutora aguardou ansiosamente a visita para o recolhimento das capas, inclusive com um pequeno papel onde tinha anotado algumas palavras sobre cada capa. Dentre as palavras escritas por ela estavam: fé, ajuda, sofrimento e união.

Estes mosaicos (Figuras 1-9) trazem imagens que foram pensadas, trabalhadas, co-criadas: os percursos de mulheres em processo de envelhecimento em nossa sociedade contemporânea por meio de um processo de labor prazeroso, oferecendo a si, no seu tempo, apresentando sua oferta ao público leitor desta pesquisa, em gestos que nos levam a diferentes usos e pertencimento de espaços, de modo a refletir sobre a construção de afetos e de partilha, a delicadeza e o respeito pela investigação, a geração de conhecimento com tudo que ele envolve, como tensões e desafios.

O livro do artista-etnógrafo elaborado nesta investigação “[...] está repleto das tensões entre invenção e tradição, atos absolutamente complementares na ordem da construção da escrita, [...]" (Barroso et al., 2008a: 7). Cada leitura fará com que ele possa se abrir ainda mais. Também é possível refletir sobre o papel do antropólogo "como mediador cultural" (Barroso et al., 2008a: 9). Num deslocamento destas escritas 
colaborativas, a forma apresenta estes arranjos, sendo o pesquisador aquele que atenta para o sensível no ato de escrever o que se mostra no percurso investigativo.

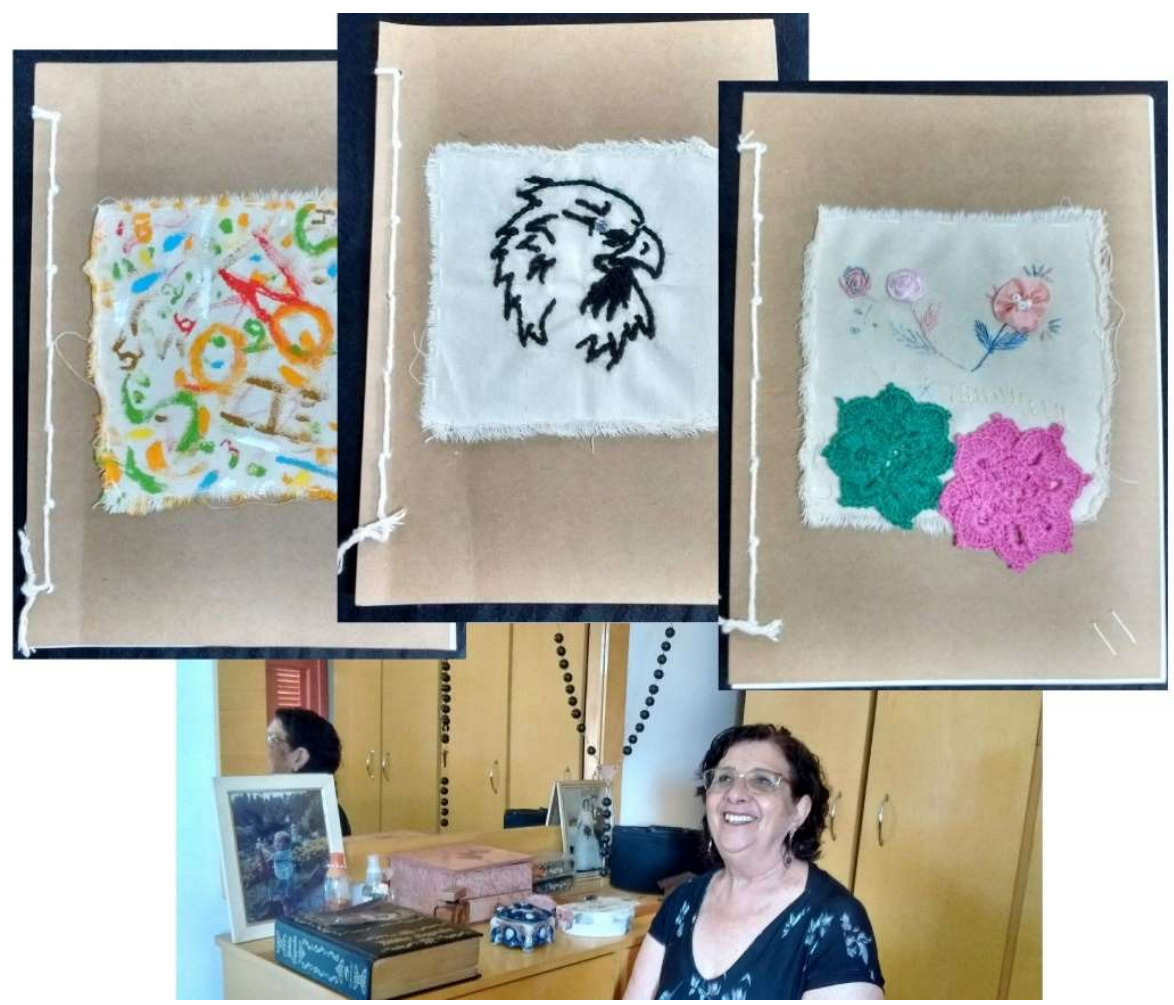

Figura 1: Fascículo II com co-autoria de Terezinha Passos. Fonte: acervo da pesquisadora.

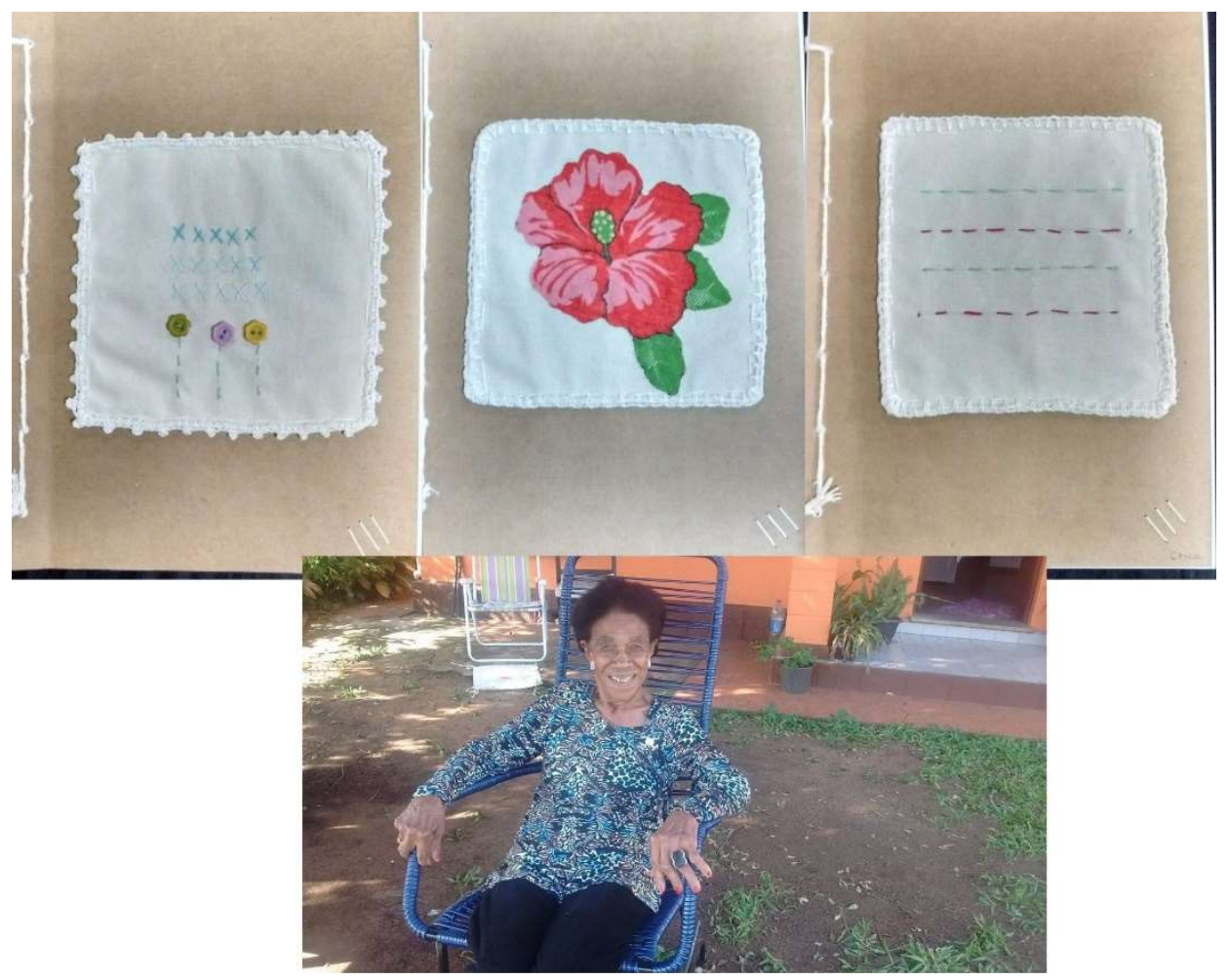

Figura 2: Fascículo III com co-autoria de Maria Emília de Mendonça. Fonte: acervo da pesquisadora. 


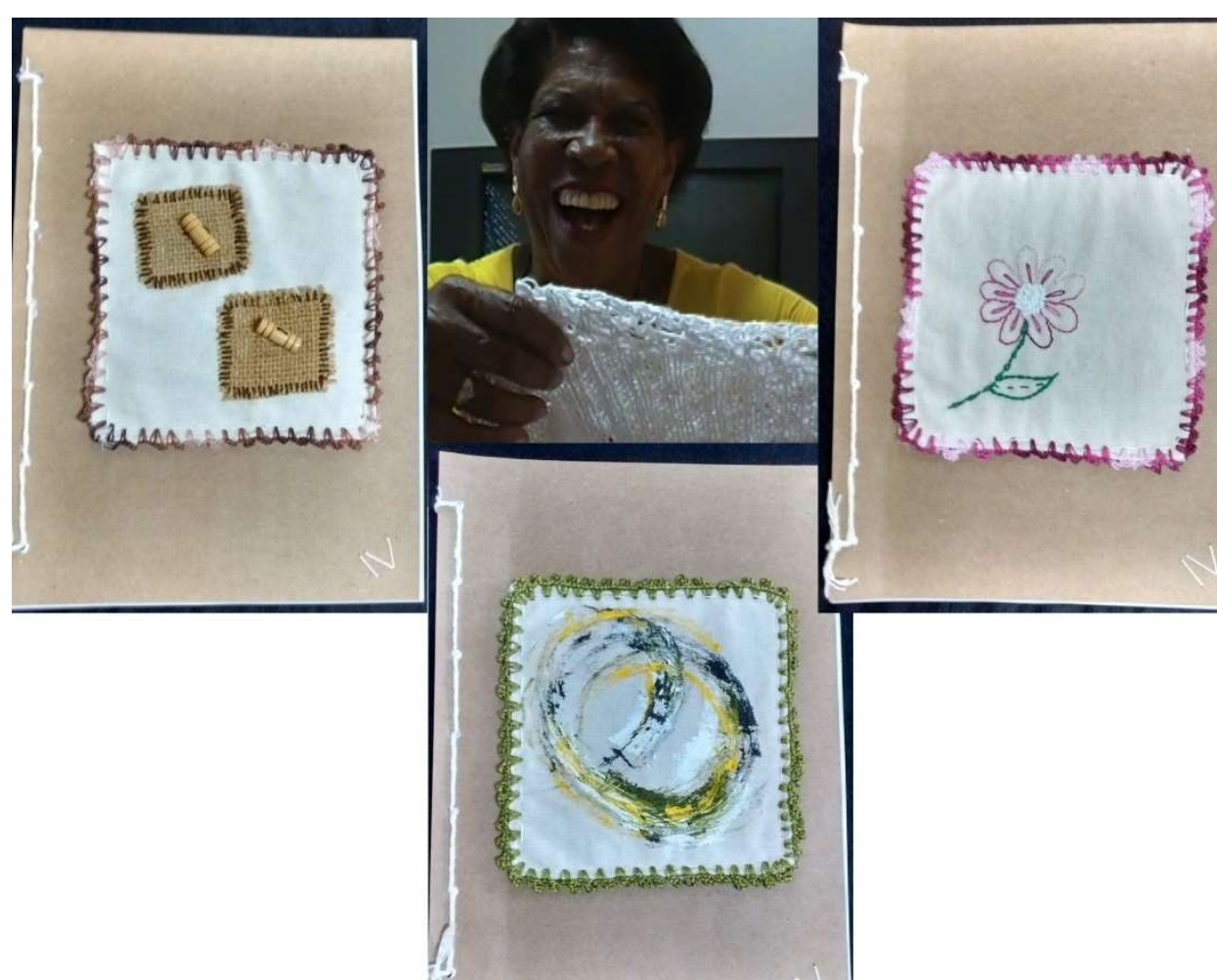

Figura 3: Fascículo IV com co-autoria de Marli Oliveira. Fonte: acervo da pesquisadora.

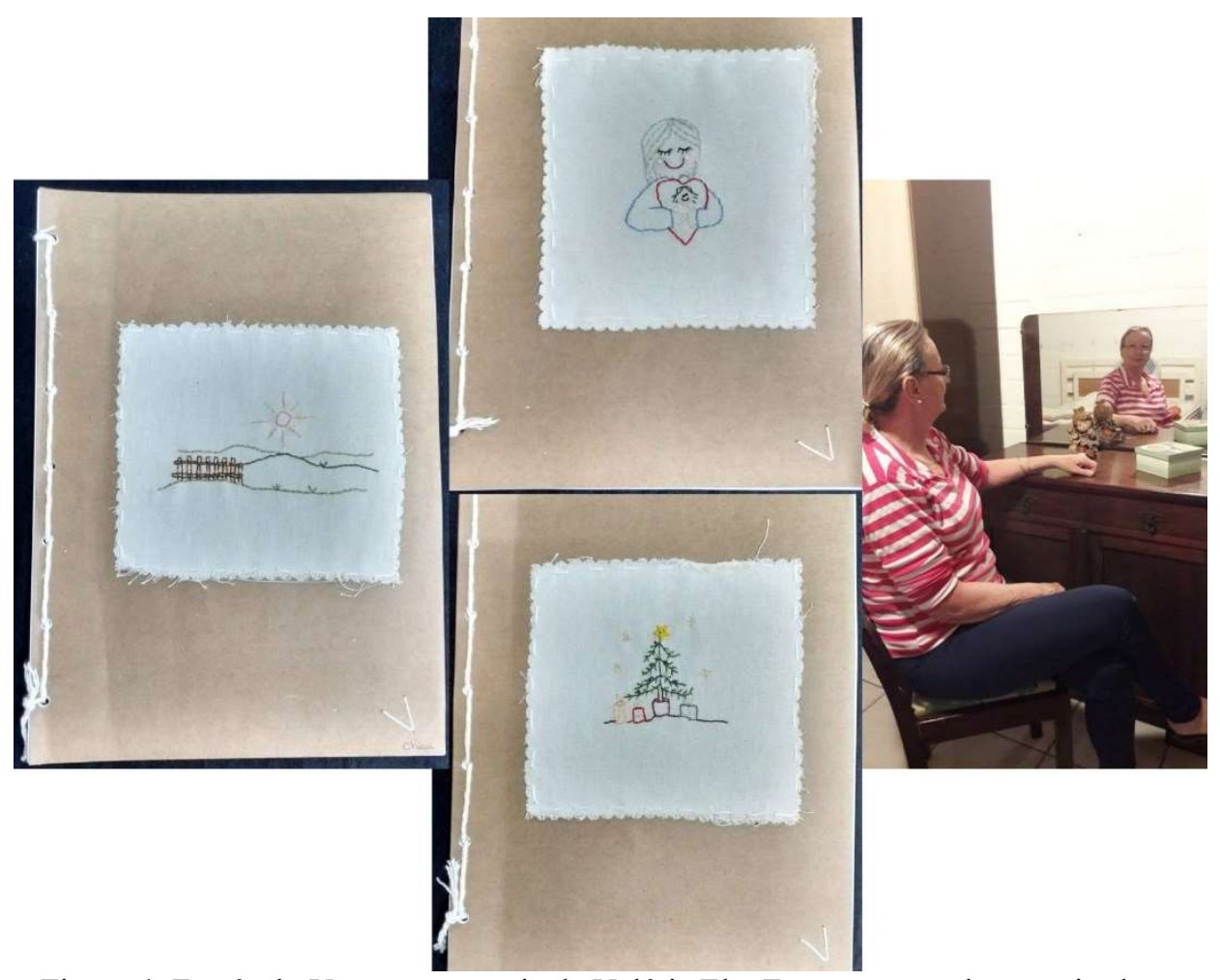

Figura 4: Fascículo V com co-autoria de Valéria Ely. Fonte: acervo da pesquisadora. 


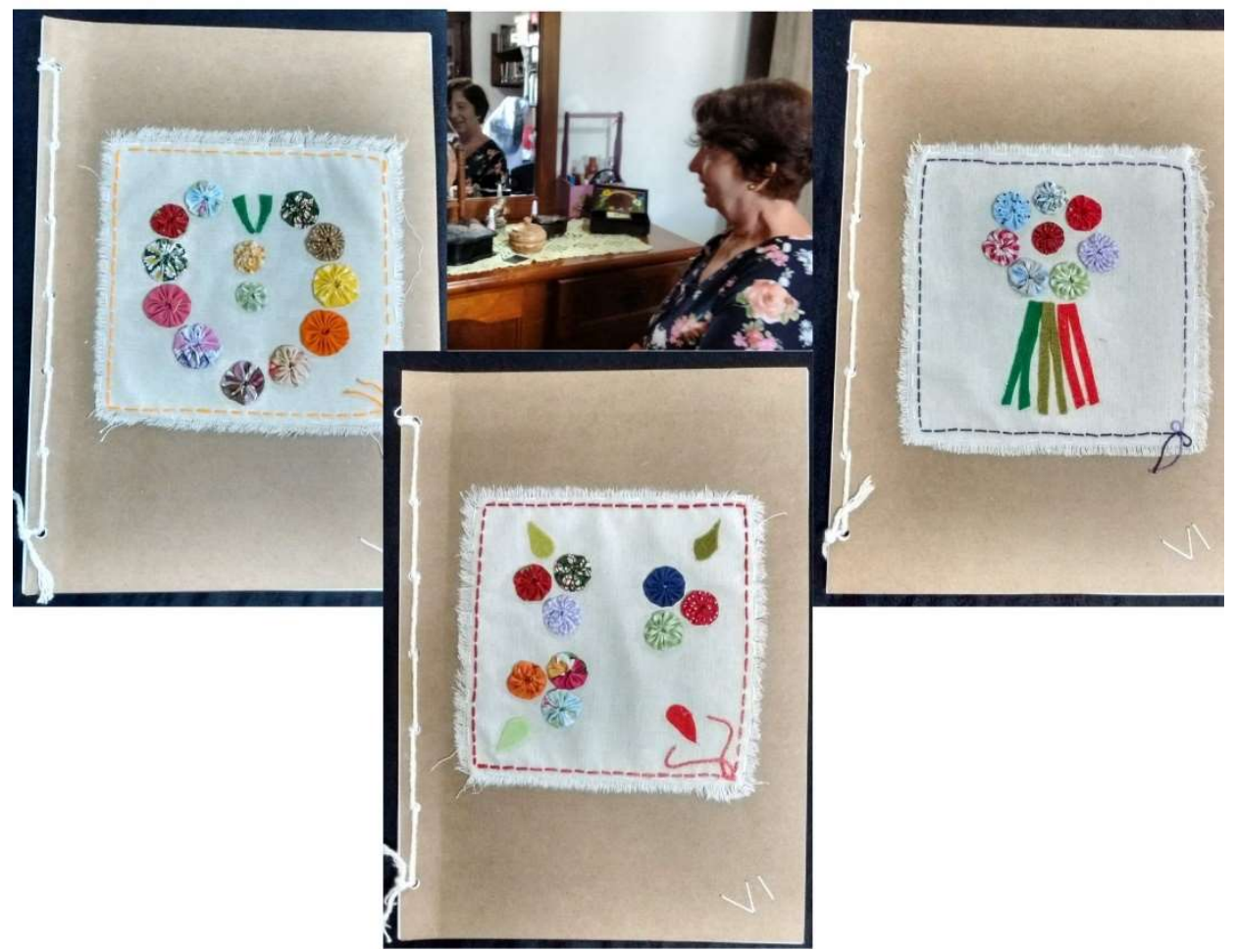

Figura 5: Fascículo VI com co-autoria de Eoní da Rosa. Fonte: acervo da pesquisadora.

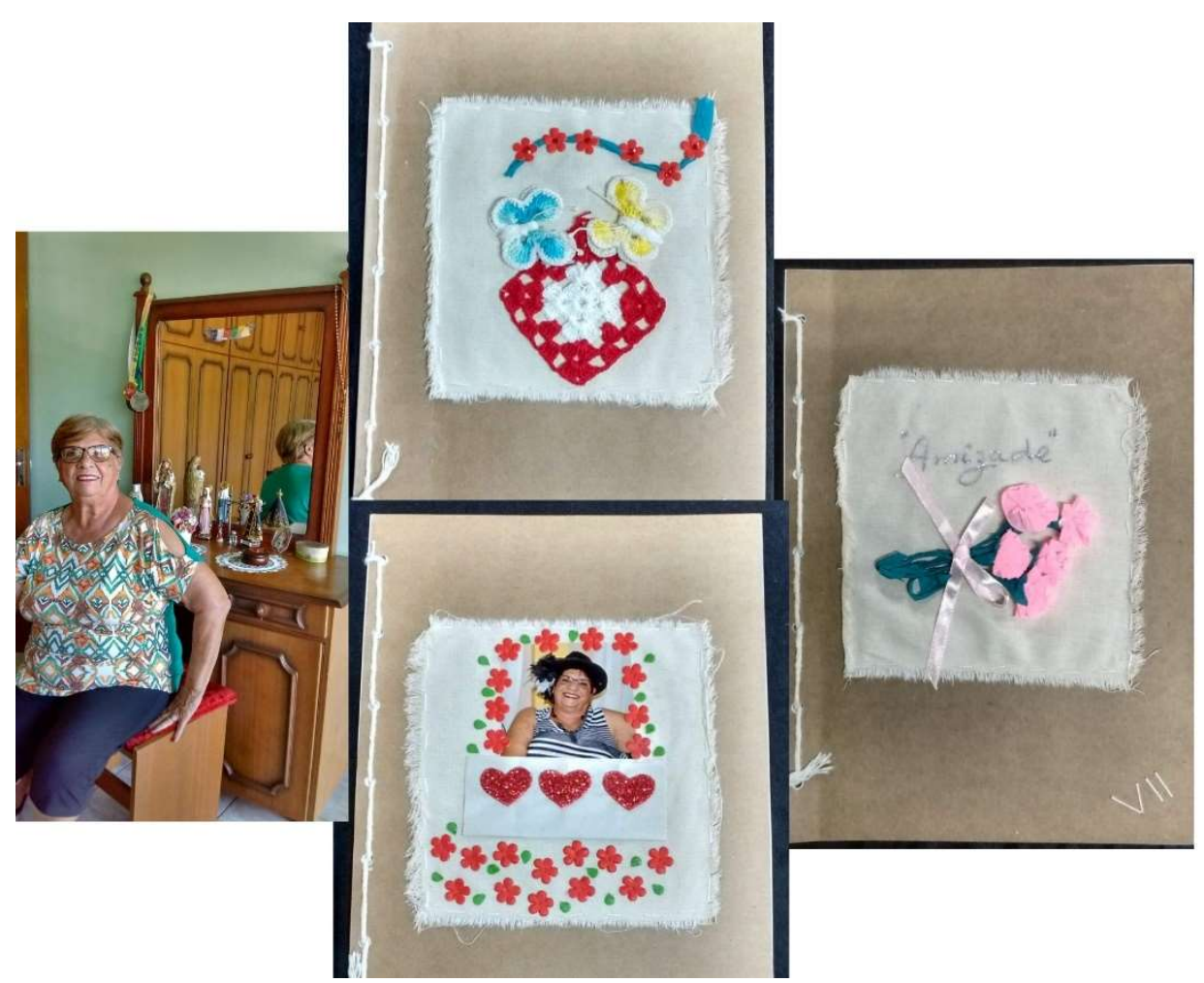

Figura 6: Fascículo VII com co-autoria de Lorena da Cunha. Fonte: acervo da pesquisadora. 


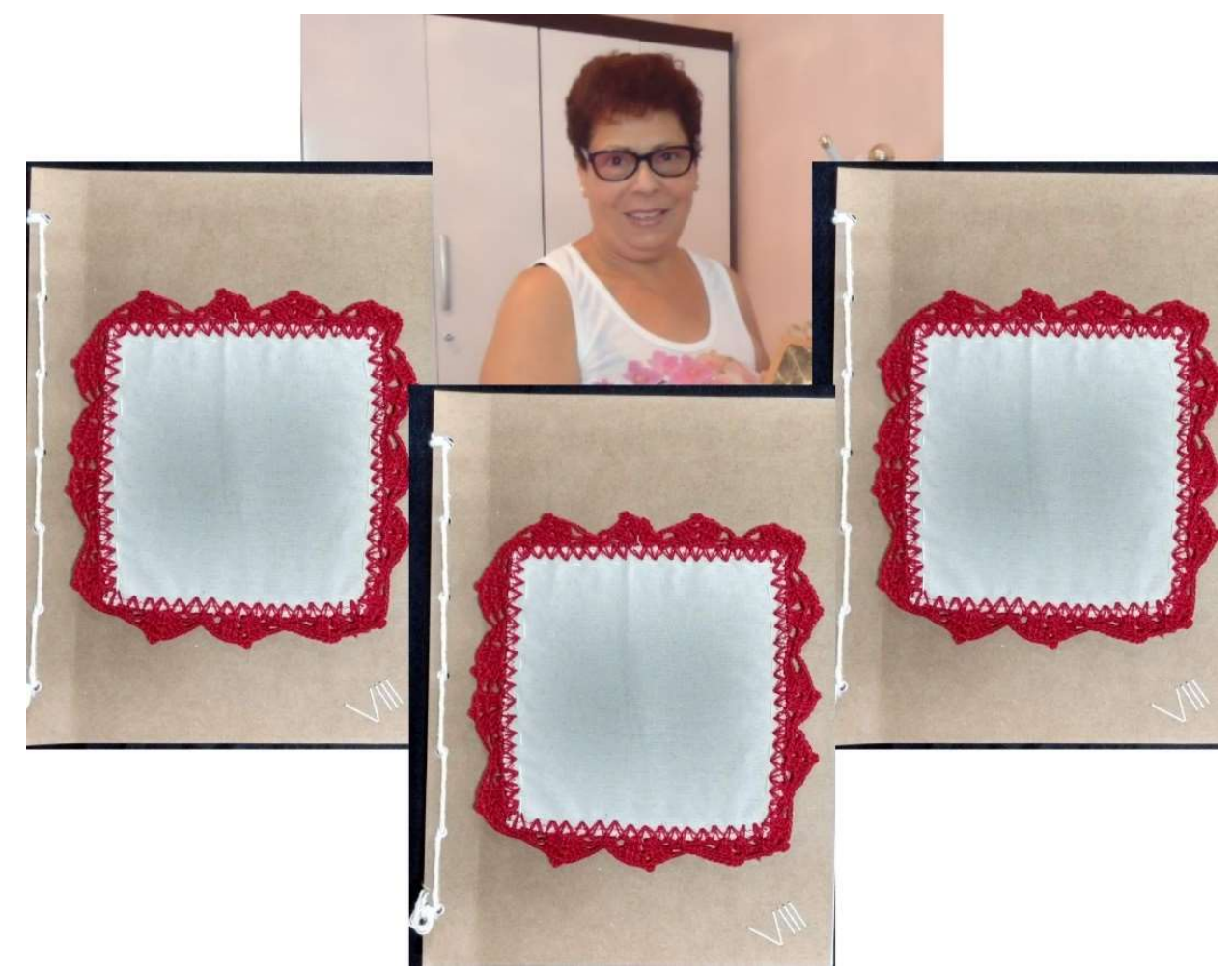

Figura 7: Fascículo VIII com co-autoria de Ana Rodrigues. Fonte: acervo da pesquisadora.

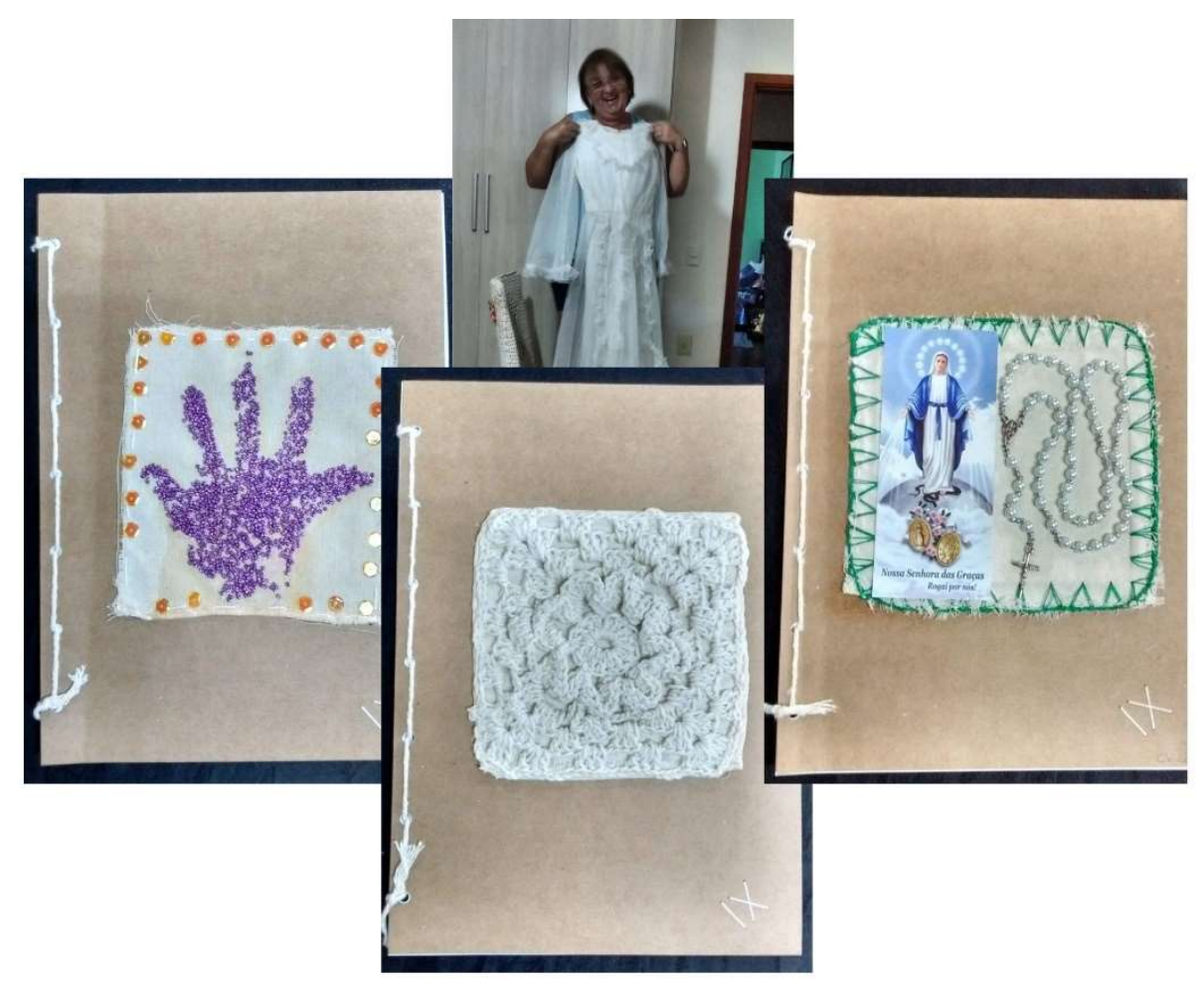

Figura 8: Fascículo IX com co-autoria de Celina de Vargas. Fonte: acervo da pesquisadora. 
As capas dos fascículos I e X (na Figura 9, juntamente com os fascículos e o volume da dissertação em forma de livro do artista-etnógrafo) ficaram ao encargo da pesquisadora, trazendo imagens de impressão digital e traços gravados ${ }^{10}$, maiores e menores, que se separam, se entrecruzam, uns soltos, outros mais presos a outros. Movimentos entre aproximação e distanciamento, ampliação e foco, o eu e o nós. O exercício de leitura, escrita, releitura e reescrita foi intenso.

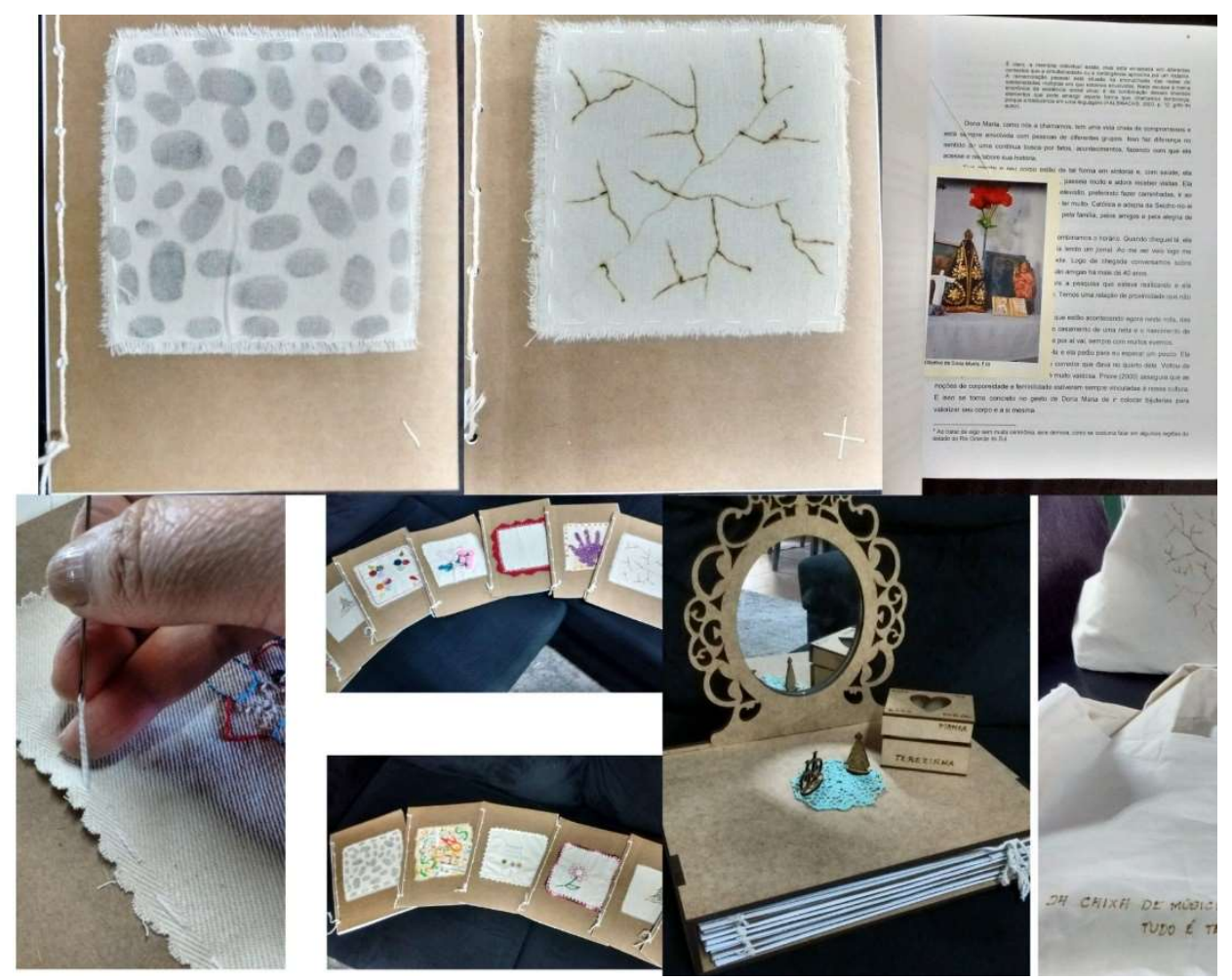

Figura 9: Fascículos e volume da dissertação como livro do artista-etnógrafo. Fonte: acervo da pesquisadora.

As palavras e as imagens se complementaram durante a pesquisa etnográfica apresentando, ora justapostas, ora sobrepostas, percepções, sensações, afetos, registros das memórias da trajetória destas mulheres. Relembrar é importante,

É claro, a memória individual existe, mas está enraizada em diferentes contextos que a simultaneidade ou a contingência aproxima por um instante. A rememoração pessoal está situada na encruzilhada das redes de solidariedades múltiplas em que estamos envolvidos. Nada escapa à trama sincrônica da existência social atual, é da combinação desses diversos elementos que pode emergir aquela forma que chamamos lembrança, porque a traduzimos em uma linguagem (Halbwachs, 2003: 12, grifo do autor).

\footnotetext{
${ }^{10}$ Com pirógrafo.
} 
Ao revisitar palavras e imagens é possível refletir que "tudo o que é lembrado, pensado, conscientizado, torna-se alicerce, moldura, pedestal, [...]" (Benjamin, 1987: 228). Nossa memória está em constante atividade, pois as muitas pessoas que nos rodeiam estão, de uma forma ou de outra, incentivando-nos através dos questionamentos sobre nossa vida. Assim, o que se oferece de modo partilhado e co-criado nesta pesquisa traz do privado ao público, e deste e neste público se multiplica.

\section{Do alinhavo à costura}

O passo a passo desta co-criação apresentou parte do vivido humano pelo grupo, sendo que a finalização desta costura por parte da pesquisadora foi uma espécie de reunião das capas, lembrando as pranchas de Margaret Mead, com a co-criação do saber fazer de cada participante. Este foi um trabalho ${ }^{11}$ muito delicado visto que era preciso respeitar a margem, a forma, as cores e as texturas. Durante a pesquisa este foi o mesmo movimento da pesquisadora, afinal estava costurando palavras, imagens, trajetórias, com respeito, admiração e cuidado.

As minipenteadeiras foram elaboradas com os dez fascículos costurados folha por folha pelas mãos da pesquisadora, trazendo as capas confeccionadas pelas mãos de cada uma das interlocutoras simbolizando a relação de afeto e pertencimento à pesquisa. As falas e imagens foram se costurando aos estudos teóricos e à construção da pesquisadora enquanto etnógrafa.

Algumas das mulheres produziram guardanapos de crochê para serem colocados sobre as minipenteadeiras, onde pequenos objetos se organizaram, lembrando as imagens observadas nos quartos das parceiras de pesquisa. Para transportar a dissertação em forma de livro de artista-etnógrafo foi elaborada uma sacola de algodão cru, juntamente com Terezinha, a parceira de pesquisa que deu início a rede social destas mulheres. Na sacola foram gravadas as informações identificando a pesquisa. Este 'kit' de pesquisa foi elaborado a muitas mãos. Cada palavra, imagem, portão e gaveta abertos, silêncios, ponto dado, agulha e linha escolhida, compôs essa escrita arte-etnográfica.

Os fascículos foram tão bem "costurados" que na finalização da montagem entendeu-se que seria importante que as interlocutoras pudessem guardar um novo objeto em sua residência, que marcasse esse período vivido. Assim, foram confeccionadas

\footnotetext{
${ }^{11}$ Costura à mão, com pequenos pontos em linha crua sob o tecido de algodão cru.
} 
minipenteadeiras, uma para cada uma delas, contendo um bloco com as imagens que foram realizadas durante a pesquisa, deixando folhas em branco para que elas possam olhar, escrever, desenhar, pintar, dando espaço para além da pesquisa, porque a pesquisa não se fecha, ela não ela encerra nesse momento de entrega da dissertação na academia. Tudo aquilo que se pensou e relembrou diante desses objetos de penteadeira são para além disso: elas trouxeram muitos momentos marcantes de suas vidas, tanto positivos quanto negativos, a trajetória de cada uma delas e esse momento é importante que seja retribuído com respeito, atenção e carinho.

Esse retorno foi um modo concreto de retribuir o tempo, os momentos que foram relembrados, os movimentos realizados e para que se pudesse partilhar a conquista, que é de todas as mulheres em processo de envelhecimento participantes desta construção de conhecimento e que mostraram uma diversidade de identidades narrativas e contribuíram para a realização deste livro de artista-etnógrafo.

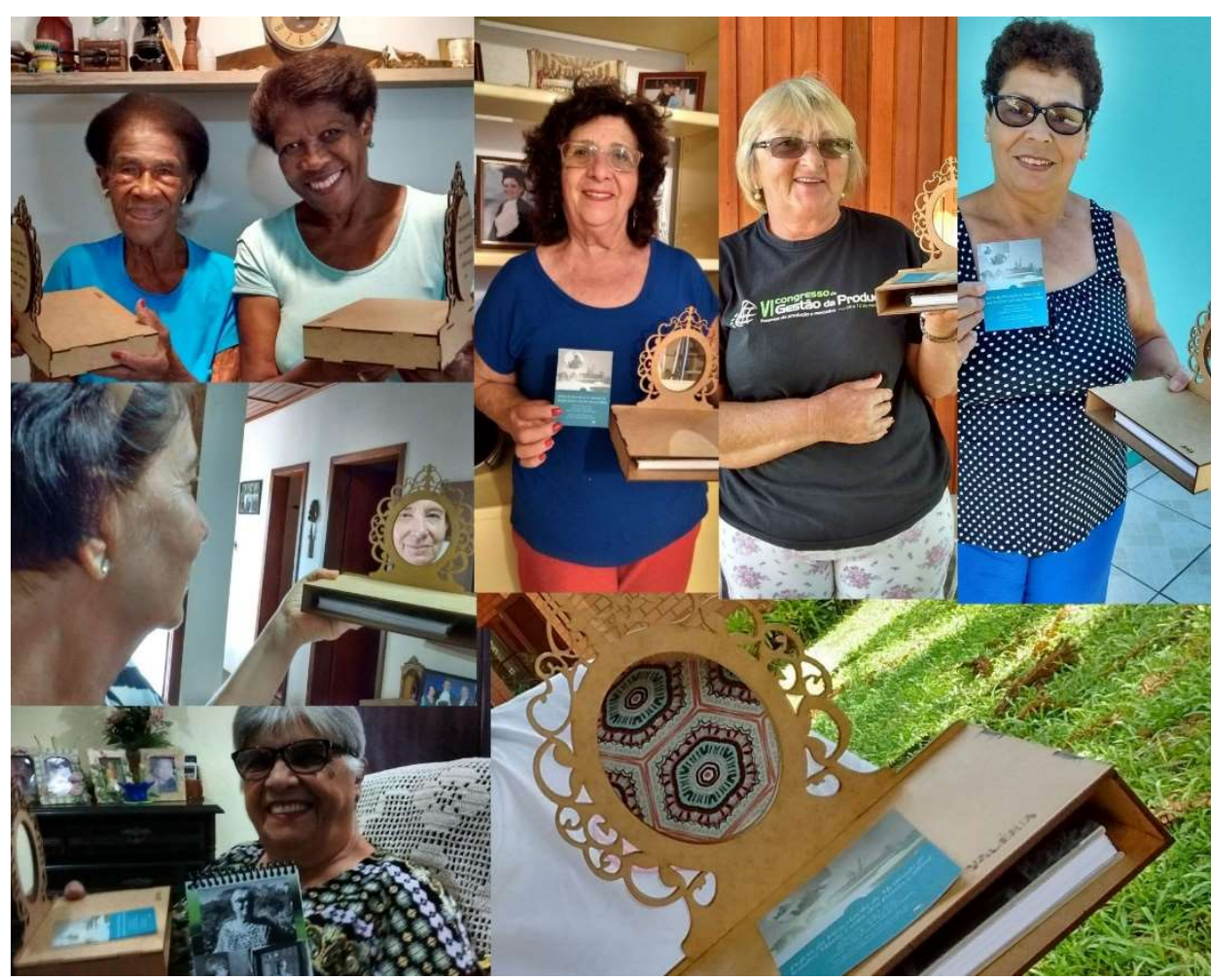

Figura 10: Recebimento das minipenteadeiras. Fonte: acervo da pesquisadora.

Foram muitos quilômetros percorridos durante a pesquisa, em dias e situações diversas onde, em alguns momentos, uma narrativa se cruzava com a outra e com um livro ou artigo que havia sido lido, mostrando assim a multiplicidade de caminhos que foram se construindo ao longo do percurso bem como a diversidade da relação entre 
pesquisadora e interlocutoras. Há caminhos infinitos que podem ser percorridos, onde palavras e imagens apresentam, em sintonia, o que foi pensado, vivido, sentido.

Algumas "coisas antigas, aparentemente há muito esquecidas, são preservadas dentro de nós, continuam a agir dentro de nós - frequentemente sem que as percebamos - e de repente vêm à superfície e começam a nos falar" (Fischer, 1983:17). Inclusive a própria ideia do espelho na penteadeira: ele nos mostra algo em sua superfície, mas também pode oferecer uma imersão quando se observam as transformações que ocorreram no tempo, no espaço, no corpo, por dentro e por fora dele. Entre utopias e distopias, para além do gesto narcísico, uma percepção caleidoscópica sobre o que se vê diante do espelho pode nos arrebatar de outros modos.

\section{Pensamentos entre arte e etnografia}

Durante a etnografia e os percursos realizados em arte, de forma colaborativa, foi possível compreender que "é necessário dominar, controlar e transformar a experiência em memória, a memória em expressão, a matéria em forma" (Fischer, 1983: 14). Esta foi a base deste processo de co-criação onde se percebeu na prática que "o campo, quando visto da perspectiva da etnografia em colaboração, permite vislumbrar possibilidades de revitalizar o fazer antropológico" (Mejía, 2015: 107).

E esta colaboração se utilizou dos recursos artísticos que cada parceira de pesquisa já dominava. Zamboni (2012: 53) reforça em seus registros que "hipótese em Arte significa mais um desejo e uma expectativa do que poderá ocorrer em termos de resultado final", relembrando que a expectativa é maior em relação ao processo. O processo criativo é, sem dúvida, a essência da criação em arte: determinar que formas serão representadas, os meios de produção, os materiais, tudo necessariamente precisa "falar" entre si. A "arte é o meio indispensável para essa união do indivíduo com o todo" (Fischer, 1983: 13).

Numa pesquisa que envolve arte e a etnografia, é imprescindível "a materialização de uma obra embasada pelas ideias e interpretações da observação" (Zamboni, 2012: 56). Para além das intenções do artista, está o processo criativo. E, por este modo, tão sutil e tão intenso ao mesmo tempo. Bourdieu (2011b: 20) assegura que "o cume da arte está em ser-se capaz de pôr em jogo coisas teóricas muito importantes a respeito de objetos ditos empíricos muito precisos". As ditas "coisas" pesquisadas envolvem o "eu" do artista, ele está presente e presentificado em todo campo da pesquisa. Esta fala para o artista, o tempo 
todo. Tanto pesquisadora quanto parceiras desta investigação se dispuseram a abrir espaço para o ato criativo e para a reunião destas criações de forma engendrada. O que Ana Luiza Rocha e Matheus Cervo (2019), explicitam de forma bastante contundente, como a dimensão híbrida e processual que entrelaça, numa complexa trama, os fazeres e saberes antropológicos aos oriundos do campo artístico, não mais apenas a literatura, mas as artes visuais e plásticas, e para além do que se costuma denominar de "artetnografia", como uma forma de nos situarmos no interior de uma antropologia colaborativa, mais do que compartilhada, como assim projetava Jean Rouch (Hikiji, 2013).

Como Krauss (2007) traz em seus registros, o prazer da procura atinge o ápice da criação, sendo o procedimento prático apenas uma ação por si só. E esta foi a expectativa deste trabalho de construção de uma dissertação de mestrado, diante de tantas possibilidades que se tinha em mãos, para expressar os conhecimentos antropológicos adquiridos com as interlocutoras da pesquisa: a natureza humana como temática e material poético apresentando uma simples, mas complexa co-criação.

A magia da combinação dos diferentes e da conexão entre estes se percebe no ato criativo. A soma, o enredar de muitos, para operar a partilha. Para Baudrillard (1991: 8) "é na diferença que consiste na poesia do mapa e o encanto do território". Assim, a mente humana é capaz de produzir imagens para muito além do que se vê. Trazer à luz uma forma representando o que se percebe numa relação entre duas partes pode ser um trabalho doloroso, intenso e parecer, por vezes, inconcebível. Afinal, "toda a arte tem origem na mente humana, em nossas reações ao mundo em vez do próprio mundo visível" (Gombrich, 1960: 76). Assim, o que define a possibilidade da criação é o modo como se reage às dificuldades e aos apelos que surgem pelo trajeto. Quando se está aberto a perceber e conceber a arte, algo de muito precioso acontece, a magia do processo criativo. Pois

\footnotetext{
Em todas as suas formas de desenvolvimento, na dignidade e na comicidade, na persusação e na exageração, na significação e no absurdo, na fantasia e na realidade, a arte tem sempre um pouco a ver com a magia. A arte é necessária para que o homem se torne capaz de conhecer e mudar o mundo. Mas a arte também é necessária em virtude da magia que lhe é inerente (Fischer, 1983: 20).
}

As parceiras de pesquisa foram protagonistas com suas narrativas e, para além delas, com suas criações artísticas produziram a partir do que foi vivido durante a investigação, elaborando a dissertação num ato de co-criação. Estas elaborações reunidas 
saíram do formato acadêmico tradicional passando a apresentação de um livro de artistaetnógrafo. No decorrer do percurso a etnografia promoveu a possibilidade de arranjos para os diferentes registros da participação social, e então a arte se entrelaçou nesta construção de conhecimento tão singular.

"Cada acontecimento está vinculado ao contexto social em que a ação humana é desenvolvida" (Eckert, Rocha, 2008: 13). Assim, são os fatos que orientam o percurso da pesquisa. O etnógrafo faz seu roteiro, organiza os materiais, sua rede social, entra em campo e a pesquisa cria um corpo próprio.

\begin{abstract}
Sem dúvida, não é possível conferir valor transcendental aos conteúdos empíricos nem deslocá-los para o lado de uma subjetividade constituinte, sem dar lugar, ao menos silenciosamente, a uma antropologia, isto é, um modo de pensamento em que os limites de direito do conhecimento (e, consequentemente, de todo o saber empírico) são ao mesmo tempo as formas concretas da existência, tais como elas se dão precisamente nesse mesmo saber empírico (Foucault, 2007: 342).
\end{abstract}

Assim como Foucault traz Nietzsche para pensar na vida como uma obra de arte, podemos nos arriscar a dizer que os relatos e seus fazeres artísticos conformaram-se em uma obra de arte conjunta: pesquisadora e parceiras de pesquisa co-criaram forma e conteúdo, num processo expressivo que reuniu as manifestações culturais de mulheres em processo de envelhecimento diante do desfolhar do tempo narrado.

Movimentos do privado ao público e do público ao privado, cerzindo, alinhavando, costurando, bordando. Atos não automáticos, mas pensados, vividos. Em cada gesto da elaboração deste livro arte-etnográfico estavam desenhados no espaço as memórias destas mulheres em momentos vividos. Arte e etnografia num arranjo poético coletivo, problematizando, comunicando e partilhando conhecimento, pois

[...] podemos considerar que na experiência etnográfica faz-se presente uma forma de atitude cultural semelhante ao campo das artes, em que os agentes envolvidos, em ambas construções, etnográfica e artística, buscam uma espécie de experiência 'autêntica' (Fernandes, 2008: 153, grifo do autor).

\title{
Considerações finais
}

As análises sobre as narrativas e imagens coletadas ao longo da pesquisa se aprofundaram na manifestação cultural presente nestas relações. É possível afirmar que as interlocutoras foram protagonistas da construção da pesquisa e da elaboração da dissertação, com significados próprios. A ideia de co-autoria esteve presente durante o 
percurso do trabalho em campo, num aprendizado contínuo de olhar para o outro, as coisas, o mundo.

As imagens produzidas pelas interlocutoras da pesquisa 'falam' de um lugar, trazem a relação do sujeito com e no mundo, representando assim uma paisagem ${ }^{12}$ vivida. Ao tratar da produção do conhecimento no campo da antropologia visual Rocha (1995: 110) possibilita a reflexão sobre a construção do simbolismo imaginário, afirmando “[...] que a imagem é parte integrante do texto etnográfico, denunciando o que existe de desconhecido e inacabado na sua escritura".

A relação entre a pesquisadora e as interlocutoras se deu com naturalidade, sendo construída de forma ética, com confiança mútua. A construção da pesquisadora como etnógrafa possibilitou o aprendizado de que a pesquisa cria um corpo próprio e que é necessário ter flexibilidade e atenção nas leituras tanto dos teóricos quanto dos objetos e processos que estão sempre em movimento, num constante devir. Afinal, as biografias são dinâmicas, para além delas mesmas, sendo necessária a capacidade de realmente escutar e acolher o que elas comunicam, estando aberta em campo, com uma postura sensível e respeitosa com o tempo de cada uma das interlocutoras.

No momento das escritas e reescritas é importante estar despida das certezas, não ter medo de produzir ambiguidades, de possuir receios nas escolhas, mas de fazê-las de modo que a estratégia narrativa ofereça a possibilidade de se perceber o poder das coisas, de se debater a partir disso, refletindo sobre as relações que se estabelecem, os ritos cotidianos, as emoções, a espera, o silêncio.

\section{É possível compreender o fato de que cada mulher, em seu tempo e lugar, tem um itinerário único, mas que pode influenciar, direta ou indiretamente, o caminho de outras mulheres. Este é o arremate final de uma costura que foi se fazendo aos poucos, por muitas mãos. O que era apenas um tecido frágil, ganhou outra forma, com mais densidade, outras cores e texturas. Ele se apresenta para além do molde da intenção inicial, pois foi se construindo, trama por trama, e poderá servir para quem quiser usar do modo que entender (Colling, 2019: 172).}

As imagens mostram corpos, objetos, lugares, histórias. São, juntamente com as palavras, a escrita deste campo observado, num jogo contínuo de proximidade e distanciamento. $\mathrm{O}$ espelho, o tempo e o espaço, demonstrando a relação entre objetos e pessoas, suas transformações, à luz de estudos teóricos para a pesquisadora, mas à luz do movimento das memórias para todas as envolvidas na pesquisa pois “A memória narrada

\footnotetext{
${ }^{12}$ Com base nos estudos de Simmel (1983) e de seu paradigma estético para as formas de vida social.
} 
é a forma da vida citadina ser tomada na inteligibilidade das experiências geracionais, e que situam cada sujeito da pesquisa como um narrador" (Eckert, Rocha, 2010: 143).

A arte e a etnografia construíram este percurso de participação coletiva e social das memórias destas mulheres. Com formas de cooperação e senso de partilha esta trama ganhou densidade e atentou para outras possibilidades de ver, dizer, saber e fazer, numa constante interação de contatos e trocas.

\section{REFERÊNCIAS}

BARROSO, Priscila Farfan; LOPO, Rafael; ROCHA, Ana Luiza Carvalho da; VEDANA, Viviane. As fontes escritas do pensamento antropológico, seus dilemas e desafios - um ensaio. Iluminuras, Porto Alegre, v. 9, n. 21, p. 1-23, 2008a.

BARROSO, Priscila Farfan; LOPO, Rafael; ROCHA, Ana Luiza Carvalho da; VEDANA, Viviane. A desterritorialização dos saberes e fazeres antropológicos e o desentendimento no corpo de verdade da letra. Iluminuras, Porto Alegre, v. 9, n. 22, p. 1$23,2008 b$.

BAUDRILLARD, Jean. Simulacros e simulação. Lisboa, Relógio D’água, 1991.

BENJAMIN, Walter. Imagens do pensamento: Desempacotando minha biblioteca. In: BENJAMIN, Walter. Rua de Mão Única. Obras escolhidas, Vol. II. São Paulo, Ed Brasiliense, 1987, p. 143-277.

BOURDIEU. Pierre. Homo academicus. Florianópolis, Ed. da UFSC, 2011 a.

BOURDIEU, Pierre. O Poder Simbólico. Rio de Janeiro, Bertrand Brasil, $2011 \mathrm{~b}$.

COLLING, Sandra Maria Costa dos Passos Colling. Da caixa de música ao perfume, tudo é tesouro! Estudo etnográfico sobre mulheres em processo de envelhecimento e seus objetos de penteadeira na região do Vale do Rio dos Sinos/RS. Dissertação (Mestrado em Processos e Manifestações Culturais). Universidade Feevale. Novo Hamburgo, 2019. 
ECKERT, Cornelia e ROCHA, Ana Luiza Carvalho da. Cidade narrada, tempo vivido: estudos de etnografias da duração. Revista $R U A$, Laboratório de Estudos Urbanos, Campinas, n. 16, vol. 1, p. 121-146, junho 2010.

ECKERT, Cornelia e ROCHA, Ana Luiza Carvalho da. O tempo e a cidade. Porto Alegre, UFRGS Editora, 2005.

ECKERT, Cornelia e ROCHA, Ana Luiza Carvalho da. A narrativa e a captura do movimento da vida vivida. Iluminuras, Porto Alegre, v. 5, n. 9, p. 1-19, 2004.

ECKERT, Cornelia e ROCHA, Ana Luiza Carvalho da. Etnografia: saberes e práticas. In: Céli Regina Jardim Pinto e César Augusto Barcellos Guazzelli. (Org.). Ciências Humanas: pesquisa e método. Porto Alegre, Editora da Universidade, 2008, p. 9-24.

FERNANDES, Daniel dos Santos. Benedictu Placere: uma campanha na Amazônia Paraense. Tese (Doutorado) Instituto de Filosofia e Ciências Humanas, Programa de PósGraduação em Ciências Sociais, Universidade Federal do Pará. Belém, 2008.

FISCHER, Ernest. A necessidade da arte. Rio de Janeiro, Zahar Editores, 1983.

FOUCAULT, Michel. As palavras e as coisas: uma arqueologia das ciências humanas. São Paulo, Martins Fontes, 2007.

FOUCAULT, Michel. Estética: literatura e pintura, música e cinema. Rio de Janeiro, Forense Universitária, 2001.

GOMBRICH, Ernst. Arte e Ilusão. São Paulo, Martins Fontes, 1960.

HALBWACHS, Maurice. A memória coletiva. São Paulo, Centauro, 2003.

HIKIJI, Rose Satiko Gitirana. Rouch compartilhado: premonições e provocações para uma antropologia contemporânea. Iluminuras, Porto Alegre, v. 14, n. 32, p. 1-10, 2013. 
KRAUSS, Rosalind E. Caminhos da escultura moderna. São Paulo, Martins Fontes, 2007.

LEITE, Miriam Moreira. Retratos de família: leitura da fotografia histórica. São Paulo, Editora da Universidade de São Paulo, 2001.

MAGNANI, José G. C. De perto e de dentro: notas para uma etnografia urbana. Revista Brasileira de Ciências Sociais, São Paulo, v. 17, n. 49, p. 11-29, 2002.

MAUSS, Marcel. Sociologia e antropologia. São Paulo, Cosac Naify, 2015.

MEJÍA, Rafael Estrada. Etnografia, cartografia e devir: potencialidades da escritura nas pesquisas antropológicas contemporâneas. In: DIAS, Adriana et al. Vidas \& grafias: narrativas antropológicas, entre biografia e etnografia. Rio de Janeiro, Lamparina \& FAPERJ, 2015, p. 90-110.

RANCIÈRE, Jacques. Políticas da Escrita. São Paulo, Editora 34, 1995.

RANCIÈRE, Jacques. O desentendimento. São Paulo, Editora 34, 1996.

ROCHA, Ana Luiza Carvalho da. Tecnologias Audiovisuais na Construção de Narrativas Etnográficas, um percurso de investigação. Campos Revista de Antropologia, Curitiba, [S.1.], v. 4, p. 113-134, dez. 2003.

ROCHA, Ana Luiza Carvalho da e ECKERT, Cornelia. Antropologia em outras linguagens: considerações para uma etnografia hipertextual. Revista Brasileira de Ciências Sociais, São Paulo, v. 31, n. 90, p. 71-84, fev. 2016.

ROCHA, Ana Luiza Carvalho da e CERVO, Matheus. Antropologia em outras linguagens: experiências com o projeto "O Livro do Etnógrafo". Tessituras: Revista de Antropologia e Arqueologia, Pelotas, v. 7, n. 2, p. 213-241, 2019. 
ROCHA, Ana Luiza Carvalho da. Antropologia das formas sensíveis: entre o visível e o invisível, a floração de símbolos. Horizontes Antropológicos. Porto Alegre, Ano 1, v. 2 , 1995.

ROCHA, Ana Luiza Carvalho da e ECKERT, Cornelia. Projetos, desafios e consolidação de uma linha de pesquisa no Brasil: antropologia audiovisual. In: LANDA, Mariano Báez e ALVAREZ, Gabriel O. (org.). Olhar in(com)formado: teorias e práticas na antropologia visual. Goiânia, Editora da Imprensa Universitária, 2017. p. 25-101.

RICOUER, Paul. Tempo e narrativa 2: A configuração do tempo na narrativa de ficção. São Paulo, Editora WMF Martins Fontes, 2010.

SIMMEL, Georg. A natureza sociológica do conflito; a competição; conflito e estrutura de grupo; sociabilidade: um exemplo de sociologia pura ou formal. In: MORAIS FILHO, E. (org.). Simmel. São Paulo, Ática. 1983. p. 122-181.

STRATHERN, Marilyn. O efeito etnográfico e outros ensaios. São Paulo, Cosac Naify, 2014.

WAGNER, Roy. A Invenção da Cultura. São Paulo, Cosac Naify, 2010.

ZAMBONI, Silvio. A pesquisa em Arte: um paralelo entre arte e ciência. Campinas, Autores Associados, 2012.

Recebido: $15 / 12 / 2020$

Aprovado: 07/02/2021 